\title{
COMMENTS
}

\section{Lawmaker as Lawbreaker: Assessing Civil Penalties Against Federal Facilities Under RCRA}

\author{
Elizabeth Cheng†
}

\section{INTRODUCTION}

On June 6, 1989, seventy agents from the FBI and EPA, armed with a search warrant, entered the Department of Energy's Rocky Flats nuclear weapons plant in Colorado. Capping a tenmonth criminal investigation, the search exposed evidence of a wide range of environmental violations, including the secret incineration of hazardous wastes, false claims of compliance with groundwater monitoring requirements, and intentional mixing of hazardous and radioactive wastes. ${ }^{1}$

The Rocky Flats incident is a particularly dramatic but nonetheless accurate reflection of the type of environmental problems created by federal facilities. By the mid-1970s, the federal government had adopted statutes governing almost every major environmental threat, including air emissions, pesticides, and hazardous waste dumping. As the 1990s commence, one great irony is that the federal government continues to be a major violator of its own laws. From the Portsmouth Naval Shipyard in Maine to the Feed Materials Production Center in Ohio to the Hanford Reservation in Washington, almost every state in the country faces pollution problems caused by the activities of federal facilities. ${ }^{2}$ The prob-

$\dagger$ A.B. 1987, Stanford University; J.D. 1990, The University of Chicago.

1 Federal Facilities Compliance Act of 1989, Report of the Committee on Energy and Commerce, HR Rep No 101-141, 101st Cong, 1st Sess 4 (1989).

${ }^{2}$ Id at 3-40 (testimony and correspondence to Congress from forty-five states regarding federal facility environmental problems). 
lem posed by hazardous wastes is particularly acute. The Department of Defense (DOD) and the Department of Energy (DOE) generate twenty million tons of hazardous or mixed hazardous and radioactive waste each year. ${ }^{3}$ As of April 1989, according to the EPA, forty-four of eighty-two federal land disposal facilities were in "significant noncompliance" with the Resource Conservation and Recovery Act (RCRA)."

RCRA, passed in 1976, established a "cradle-to-grave" scheme of measures-including permits, monitoring, and recordkeeping-for regulating the generation, transport, treatment, and disposal of solid waste. ${ }^{5}$ The federal government has repeatedly sought less stringent application of these rules to its facilities than to private industry or state and local governments. ${ }^{6}$ For instance, the DOE maintained that the Atomic Energy Act precluded application of RCRA to its facilities, until a federal district court ruled otherwise in 1984. ${ }^{7}$ The DOE next proposed that RCRA did not apply to hazardous waste containing "by-product" material, which would exempt much of the DOE's mixed hazardous and radioactive waste; ${ }^{8}$ the Department eventually abandoned this position in May, $1987 .^{\circ}$ Federal facilities have also benefited from the Department of Justice's position that the EPA does not have enforcement

Id at 3.

42 USC $\S$ 6901-6992 (1982 \& Supp 1989). Federal Facilities Compliance Act of 1989, S 1140, 135 Cong Rec S6333 (June 7, 1989) (introductory statement by Senator Frank Lautenberg).

- Note, How Well Can States Enforce Their Environmental Laws When the Polluter is the United States Government?, 18 Rutgers L J 123, 126-27 (1986).

- Environmental Compliance by Federal Agencies, Hearings on HR 1056 before the Subcommittee on Transportation, Tourism, and Hazardous Materials of the House Committee on Energy and Commerce, 101st Cong, 1st Sess 16-19 (1989) ("Hearings on Federal Compliance") (statement of Kenneth 0 . Eikenberry, Attorney General, State of Washington).

7 Legal Environmental Assistance Foundation, Inc. v Hodel, 586 F Supp 1163 (E D Tenn 1984).

8 Hearings on Federal Compliance at 16 (cited in note 6).

- Cleanup at Federal Facilities, Hearings on HR 3781, HR 3782, HR 3783, HR 3784, and HR 3785 before the Subcommittee on Transportation, Tourism, and Hazardous Materials of the House Committee on Energy and Commerce, 100th Cong, 2d Sess 128 n 5 (1988) ("Hearings on Federal Cleanup") (statement of Roger Stanley, Hanford Project Manager for the Washington State Department of Ecology). 
authority against sister agencies. ${ }^{10}$ Today, federal facilities are focusing on opposing certain enforcement measures in RCRA cases. ${ }^{11}$

The long history of RCRA noncompliance and legal maneuvering has prompted proposal in Congress of the Federal Facilities Compliance Act of 1989 (FFCA). ${ }^{12}$ This series of amendments to RCRA would clarify that federal facilities are subject to a range of enforcement measures, whether used by the EPA, states, or citizens, while limiting the personal civil liability of employees and the criminal liability of the agencies. The Senate version would, in addition, implement an inspection program. As of June 1990, the House had already approved the Act, by a vote of $380-39,{ }^{13}$ but the Senate Committee on Environment and Public Works had not yet acted.

This Comment focuses on the question of whether, under the current version of RCRA, states should be able to use civil penalties against the federal government. Section I establishes the textual basis in RCRA for the availability of civil penalties. Section II examines the issue from several different policy angles, and concludes that civil penalties can be justified, or at least defended, from each viewpoint.

\section{Statutory INTERPRETATION}

The doctrine of sovereign immunity shields the government from suit without its consent. Accordingly, federal facilities are subject to environmental laws only to the extent specified by Congress. Most of the current RCRA controversy has centered on whether $\S 6961$, the federal facilities provision, permits states to assess civil penalties under state law. ${ }^{14}$ Federal district courts in

10 The EPA currently defers to the Department of Justice's position that: (1) the EPA cannot sue a sister agency because such controversies are not justiciable; and (2) the EPA cannot issue enforcement orders against a sister agency because the executive branch is "unitary." Hearings on Federal Cleanup at 180, 186-87 (cited in note 9). The Justice Department's second position is inconsistent with the EPA's own original understanding of its enforcement powers, id at 187, and both arguments have been challenged by a Congressional Research Service study. Id at 180-81, 188-90. See also Michael W. Steinberg, Can EPA Sue Other Federal Agencies?, 17 Ecol L Q 317 (1990).

11 Hearings on Federal Compliance at 156 (statement of Daniel Reicher, Natural Resources Defense Council) (cited in note 6).

12 Federal Facilities Compliance Act, HR 1056, 101st Cong, 1st Sess (February 22, 1989), in 135 Cong Rec H327 (February 22, 1989) (for full text, see HR Rep No 101-141 at 2 (cited in note 1)); and S 1140, 101st Cong, 1st Sess (June 7, 1989) in 135 Cong Rec S6333 (June 7, 1989).

2s Vote on HR 1056, 135 Cong Rec H3932 (July 19, 1989).

14 Alternative theories are that the EPA or citizens can seek penalties against federal facilities. RCRA $\S \S 6928(\mathrm{a})$ and $(\mathrm{g})$ permit the EPA to assess civil penalties against any 
Maine and Ohio have held that $\S 6961$ does waive the federal government's immunity to penalties. ${ }^{15}$ As this Comment went to press, the Sixth Circuit reversed the Ohio district court's ruling on $\S$ 6961, but found state penalty authority under a different RCRA provision (see note 14). The Tenth Circuit also very recently joined the Ninth Circuit and a North Carolina district court in declining to permit penalties under $\S 6961 .^{16}$

Before examining the language of RCRA, it will be helpful to place in context the civil penalties involved in these cases. Civil penalties are, undeniably, remedial measures designed to enforce environmental duties. They are fines for violating the law, not compensatory damages. In theory, they can be administratively assessed or court-ordered; this Comment will focus on the latter. They are also one of an array of remedial tools, ranging from injunctions to administrative orders to criminal sanctions, that federal enforcers can use under RCRA against private or state and local government violators. ${ }^{17}$ Injunctions and sanctions to enforce them are explicitly available to state enforcers under \$6961; this Comment contends that the statute also grants states the discretion to use civil penalties.

\section{A. Text of RCRA}

Section 6961 states that any federal "department, agency, and instrumentality" that has "jurisdiction over" or handles solid or hazardous waste:

\footnotetext{
"person" who violates the statute, but the definition of "person" in $\S 6903(15)$ does not include the United States, although it does include states and municipalities. Moreover, the EPA currently defers to the Department of Justice's position that the EPA should not act against sister agencies. See note 10. Section 6972 authorizes citizen suits against violators. States have tried to sue for penalties directly under RCRA by claiming citizen status. Although $\S 6972$ (a) explicitly includes the United States in its definition of "person," it incorporates the penalty provisions of $\S 6928$, which appears not to apply to the United States. The Sixth Circuit has recently authorized state penalties under $\S 6972$, reasoning that because $\S 6972$ incorporates $\S 6928$, not vice versa, the definition from $\S 6972$ applies. State of Ohio v United States Department of Energy, 1990 WL 77227, *7 (6th Cir 1990). But see McClellan Ecological Seepage Situation v Weinberger, 655 F Supp 601, 603-04 (E D Cal 1986) (argument rejected); and United States $v$ State of Washington, 872 F2d 874, 880-81 (9th Cir 1989) (issue raised but not decided).

${ }^{15}$ State of Maine $v$ Department of Navy, 702 F Supp 322 (D Me 1988); and State of Ohio, 689 F Supp 760.

${ }^{18}$ Mitzelfelt $v$ Department of the Air Force, 903 F2d 1293 (10th Cir 1990); State of Washington, 872 F2d 874; and Meyer v Coast Guard, 644 F Supp 221 (E D NC 1986). See also McClellan, 655 F Supp 601.

17 RCRA, 42 USC $\S \S 6928(\mathrm{a})$ and (g), 6903(15).
} 
shall be subject to, and comply with, all Federal, State, interstate, and local requirements, both substantive and procedural (including any requirement for permits or reporting or any provisions for injunctive relief and such sanctions as may be imposed by a court to enforce such relief), respecting control and abatement of solid waste or hazardous waste disposal in the same manner, and to the same extent, as any person is subject to such requirements, including the payment of reasonable service charges. Neither the United States, nor any agent, employee, or officer thereof, shall be immune or exempt from any process or sanction of any State or Federal Court with respect to the enforcement of any such injunctive relief. ${ }^{18}$

Since a waiver of sovereign immunity "cannot be implied but must be unequivocally expressed,"18 one might say that the very existence of a dispute over the interpretation of the text proves that Congress has not waived the immunity. However, the waiver of immunity is equivocal only if one adopts an extremely narrow and formalistic reading of the statute. A more straightforward reading of the text shows that Congress intended not to give federal facilities any special treatment.

When all of the clarifying and descriptive clauses are stripped away, the central statement of the provision is that federal facilities "shall" be subject to "all Federal, State, interstate, and local requirements ... in the same manner, and to the same extent, as any person is subject to such requirements ...." The term "shall," according to conventional statutory construction, means that the prescribed actions are mandatory. The phrase "in the same manner, and to the same extent" as any other polluter makes it clear that federal facilities should not be exempted in any way. The use of the word "all" before "requirements" establishes the comprehensive scope of the rules and regulations that apply to federal facilities.

The broad meaning of the term "requirements" is established by the clauses that follow it. The phrase "both substantive and procedural" could be read as dividing the world of requirements into halves-substantive and procedural-or it could be read to illustrate, without limiting, types of requirements. Either way, civil penalties fall within the scope of the clause. Under the first inter-

1842 USC § 6961.

10 United States $v$ King, 395 US 1, 4 (1969), quoted in United States $v$ Mitchell, 445 US 535, 538 (1980). 
pretation, civil penalties fall into the category of procedural requirements; they are like injunctions and the accompanying sanctions that appear in the parenthetical clause, which, under this interpretation, is illustrative of procedural requirements. Under the second interpretation, the phrase "both substantive and procedural" simply emphasizes that requirements can include more than just the substance of duties such as monitoring and recordkeeping. The items in the parenthetical clause suggest other possible types of requirements without exhausting them, since the clause begins with the word "including." 20 The fact that injunctive relief and accompanying sanctions are listed in the clause demonstrates that enforcement mechanisms can be types of "requirements." Taken together, these sentences all show that civil penalties fall within the scope of "requirements." Even the Sixth Circuit, in State of Ohio, conceded that "[a]n ordinary reading of the phrase 'all ... requirements' indicates that a civil penalty is a 'requirement' because a party violating the statute will be required to pay the penalty."21

The next full sentence-which states that neither the United States, nor any of its agents, employees, or officers, shall be immune from "enforcement of any such injunctive relief"- -does not limit the scope of the requirements made applicable to federal facilities by the previous sentences. In part, it merely repeats the waiver of the United States' immunity established by the inclusion of injunctive relief in the parenthetical clause of the prior sentence. The sentence adds to the provision by extending the applicability of injunctive relief to responsible individuals. ${ }^{22}$

As the district court concluded in State of Maine $v$ Department of the Navy, quoting the magistrate,

an intelligent person reading the statute would think the message plain: federal facilities will be treated the same as private institutions so far as enforcement of the solid waste and hazardous waste laws are concerned .... It is hard to imagine clearer language short of listing every possible variation of such requirements. ${ }^{23}$

${ }^{20}$ See State of Ohio, 689 F Supp at 765 n 2 (listing other applicable requirements that are not contained in the parenthetical clause).

${ }^{21}$ State of Ohio, $1990 \mathrm{WL} 77227, * 5$.

22 See Captain John H. Kongable, USAF, Civil Penalties Under the Resource Conservation and Recovery Act: Must Federal Facilities Pay?, 31 AF L Rev 21, 29 (1989).

${ }^{23}$ State of Maine, 702 F Supp at 326 (quoting Magistrate's Recommended Decision). 
Accordingly, since private and state and local government violators are subject to civil penalties, federal violators should be too.

The counter-arguments to this common sense reading all focus on the absence of any specific mention of civil penalties in $\S 6961$. The interpretive canon of expressio unius-holding that the mention of some items implies the exclusion of others-can arguably take several different forms to exclude civil penalties from $\S 6961$.

One might rely on the conceptual distinction between duties and the means used to enforce them to argue that the concept of requirements simply does not include the latter. If enforcement mechanisms are not "requirements," then the sweep of the descriptive term "all" is irrelevant, and it would seem plausible that measures beyond requirements-"non-requirements"-ought to be specifically listed before a waiver of immunity will be found. An early Ninth Circuit opinion, California $v$ Walters, appeared to use this rationale to find no waiver of immunity to criminal sanctions in $\S 6961$. Holding that criminal sanctions are an enforcement mechanism and "not a 'requirement' of state law," the court reasoned that only "[s]tate waste disposal standards, permits, and reporting duties clearly are 'requirements' for the purpose of $\S 6961$." It went on to say, "Section 6961 plainly waives . . . immunity to sanctions imposed to enforce injunctive relief, but this only makes more conspicuous its failure to waive immunity to criminal sanctions," apparently assuming that sanctions, precisely because they are not "requirements," must be specifically listed in order for immunity to be waived. ${ }^{24}$

This expressio unius line fails as a way of logically excluding civil penalties. Whatever the merits of the conceptual distinction between duties and the means used to enforce them, it is not one respected in the text of $\S 6961$ : the provision's reference to injunctions, and court-ordered sanctions for their violation, bars reading "requirements" to exclude all enforcement mechanisms. Moreover, the statute waives immunity only for requirements, not for requirements plus anything else specifically named.

Other variations on the expressio unius argument would concede that enforcement mechanisms can be considered requirements conceptually, but would limit the scope of the term for purposes of $\S 6961$ in different ways. One might contend, for instance,

\footnotetext{
24 California $v$ Walters, 751 F2d 977, 978 (9th Cir 1985). See also State of Florida Department of Environmental Regulation v Silvex Corporation, 606 F Supp 159, 163 (M D Fla 1985) (holding that state strict liability statutes are not "requirements" within the meaning of $\S 6961$ because they are not "objective" regulations).
} 
that any sanction-that is, any penalty-must be specifically listed if it is to be a "requirement" within the meaning of $\S 6961$. The most recent Ninth Circuit decision on the issue, State of Washington $v$ United States, seems to adopt this approach, ${ }^{25}$ rejecting the imposition of civil penalties because "the only unequivocal and express reference to sovereign immunity in section 6961 is directed at court-ordered sanctions for a violation of an injunction."2s The court emphasized the reference to this item in both the parenthetical clause and the sentence waiving the immunity of the federal agents and employees. The North Carolina district court apparently used the same logic in Meyer $v$ Coast Guard, holding that "[a] strict construction of the statute should limit the waiver to those penalties specifically mentioned."27

However, the text provides no support for the reading that sanctions-but no other requirements-must be specifically named in order to fall within the scope of the statute. The textual basis for treating sanctions differently from all other enforcement mechanisms seems particularly weak. In both the parenthetical clause and the sentence waiving employee immunity, court-ordered sanctions are listed in tandem with the injunctive relief that they are supposed to back up. Listing items together usually suggests that they are to be treated similarly, not that one is to be subject to a stricter standard of review for immunity waivers.

One could also try to draw a line between enforcement requirements and other requirements and claim that the former must be explicitly mentioned in order for the waiver to be applicable. The parenthetical clause could provide some basis for the argument, since by listing some enforcement mechanisms it might appear to set that category of requirements apart as one for which immunity is only selectively waived. The first response to this argument, assuming that the parenthetical does indeed only refer to enforcement mechanisms, is that the clause does not operate as an exclusive list. It begins with the word "including," which ordinarily . means that the items following are illustrative, not exhaustive.

The second response is that the parenthetical clause does not necessarily define only enforcement measures. If it does not, there

${ }^{28}$ State of Washington, 872 F2d at 877. The Ninth Circuit does quote both propositions from Walters, without addressing the apparent difference in approach, but it does so only in the section rejecting an argument to overrule Walters. Id at 879.

28 Id at 877 (emphasis in original).

${ }^{27} 644$ F Supp 221, 222 (E D NC 1986). See also McClellan, 655 F Supp at 603 ("Congress intended to waive sovereign immunity . . . insofar as process or sanctions is concermed, only as required for the enforcement of injunctive relief."). 
is little textual basis for applying the expressio unius maxim only to some types of items mentioned in it. Drawing conceptual lines between the items mentioned within the parenthetical inevitably becomes a hairsplitting and rather arbitrary endeavor. The Ninth Circuit's decision in Parola $v$ Weinberger demonstrates how this problem can arise. The Parola court held that imposing an exclusive garbage collection system was a requirement that did not need to be specifically mentioned in the statute. The Ninth Circuit attempted to distinguish Walters by arguing that states have unlimited power to "implement" but not to "enforce" environmental standards. It stated that "[p]ermits and reporting duties are means of implementing environmental standards, and are clearly state 'requirements.' An exclusive garbage collection system is more like a permit requirement than a criminal sanction." ${ }^{28}$ Using this distinction would mean, however, that implementation mechanisms do not need to be specifically mentioned, while enforcement mechanisms do. Although the Tenth Circuit in Mitzelfelt $v$ Department of the Air Force, also concluded that "requirements" can "reasonably be interpreted as including substantive standards and the means for implementing those standards, but excluding punitive measures," the court did not provide any supporting textual analysis. $^{29}$

The remaining alternative constructions would only lead to absurd results. One could suggest that the parenthetical clause constitutes an exhaustive list of all the procedural requirements available-since the clause follows the word "procedural"-or that the parenthetical clause exhausts all the requirements to which federal facilities can be subject. Either reading would exempt federal facilities from a range of monitoring, inspection, and other aspects of RCRA's cradle-to-grave approach not spelled out in the provision. Clearly, as the district court in State of Maine noted, "it would be nonsensical to require Congress to make a detailed punchlist of all of the 'requirements' set out in the entire body of environmental law of the federal government and each of the fifty states." 30

One final place where a line could be drawn in the text is at the sentence waiving the immunity of the United States and its agents. Since it is the only sentence that uses the words "immunity" and "waiver," it arguably defines all the items to which im-

\footnotetext{
28 Parole, 848 F2d at 962 n 3.

${ }^{39}$ Mitzelfelt, 903 F2d 1293. See also State of Ohio, 1990 WL 77227, *6.

so 702 F Supp at 327. See also State of Ohio, 689 F Supp at 765 n 2.
} 
munity has been waived. However, such an argument proves too much; ${ }^{31}$ it would undermine the waiver established by the previous sentences for a whole host of substantive and procedural regulations. As noted earlier, moreover, this sentence serves primarily to extend the waiver to government officials.

In sum, although the definition of "requirements" could be limited to exclude or at least to limit the availability of enforcement mechanisms, such a reading can be achieved only by importing an intent to limit into the language of the provision. The more natural reading of the term is a broadly inclusive one. As the State of Maine court noted, "[b]y the language, Congress gave a clear and explicit waiver of immunity to a generic category of 'requirements' broad enough to include, by any fair construction, civil penalties;" the definition of a requirement as " "something called for or demanded" " encompasses civil penalties, which are " "called for" " to enforce state environmental laws. ${ }^{32}$

\section{B. Historical Circumstances}

The historical context of RCRA's passage strongly suggests that Congress intended the term "requirements" to permit the use of civil penalties by states, and to encompass more than merely the items listed, whatever the type of requirement. The legislative history discounts the validity of a narrow reading of the term, and the post-enactment history, despite some tantalizing clues, cannot be relied upon to prove otherwise.

\section{Pre-RCRA history.}

RCRA was passed three months after the Supreme Court's companion decisions in Hancock $v$ Train and EPA $v$ State Water Resources Control Board. In Hancock, the Supreme Court held that state permits were not "requirements" compulsory upon federal facilities under the Clean Air Act (CAA) ${ }^{33}$ At the time, $\S 118$ of the CAA stated that federal facilities "shall comply with Federal, State, interstate, and local requirements respecting control and abatement of air pollution to the same extent that any person is subject to such requirements." 34 The Court emphasized first that

s1 State of Maine, 702 F Supp at 338 n 7; and State of Ohio, 689 F Supp at 765 n 3.

s2 State of Maine, 702 F Supp at 326-27, citing Webster's Third New International Dictionary 1929 (Merriam-Webster, 1981).

ss 426 US 167, 198 (1976).

st CAA, 42 USC $\S 1857$ (f) (1970). 
the provision did not require compliance with "all" requirements. . $^{35}$ It then went on to characterize permit systems as enforcement mechanisms, ${ }^{36}$ concluding that they were not substantive requirements and hence fell outside the scope of the statute. The Court stated:

[W]e find in the 1970 Amendments several firm indications that the Congress intended to treat emission standards and compliance schedules-those requirements which when met work the actual reduction of air pollutant discharge-differently from administrative and enforcement methods and devices-those provisions by which the States were to establish and enforce emission standards, compliance schedules, and the like. ${ }^{37}$

Although this statement might suggest that the Court viewed enforcement methods as distinct from procedural (i.e., administrative) requirements, this seems unlikely because the Court quoted with approval the Court of Appeals, which had "concluded that federal installations were obligated to comply with state substantive requirements, as opposed to state procedural requirements ...."38 The Court used the same reasoning in EPAv State Water Resources Control Board to determine that $\S 505$ of the Clean Water Act (CWA), which was virtually identical to $\$ 118$ of the CAA, did not require federal facilities to obtain discharge permits. $^{\mathbf{3 0}}$

A comparison between the language of RCRA and the CWA and CAA provisions at issue in Hancock and Water Resources indicates that Congress intended "requirements" to have a broader meaning in $\S 6961$. Most importantly, Congress inserted the word "all" before requirements in the RCRA. This responded directly to a justification the Supreme Court used for its narrow interpretations of the CAA and CWA, and so explicitly broadened the scope of "requirements." Any variation of the expressio unius argument

as Hancock, 426 US at 182 .

s6 The Court framed the central question of the case as "whether Congress intended that the enforcement mechanisms of federally approved state implementation plans, in this case permit systems, would be available to the States to enforce that duty." Id at 183 (citation omitted).

s7 Id at 185-86.

ss Id at 183.

30 EPA v State Water Resources Control Board, 426 US 200, 211-15, 227-28 (1976); Clean Water Act, 33 USC § 1323 (1970, Supp IV). 
that reads portions of the provision as exclusive is simply inconsistent with the expansive intent Congress demonstrated.

Congress also added the phrase "both substantive and procedural" after "requirements." Again, this responded to Hancock and Water Resources, which Congress regarded as having turned in part on the Court's finding that "Congress intended to treat substantive state requirements different from procedural requirements." ${ }^{40}$ Congress appeared to classify enforcement mechanisms as procedural requirements, since it listed permit systems, which the Court had characterized as enforcement mechanisms, as an example of procedural requirements. Even if enforcement sanctions such as civil penalties were not intended to be procedural requirements, the addition of the word "procedural" at least denies the narrow view of "requirements" as encompassing only substantive duties. As the court in State of Maine noted, "in reaction to the [Hancock] decision, Congress enacted language clearly intended to obviate the effect of the distinction highlighted in the [Hancock] opinion upon an effective comprehensive waiver of sovereign immunity."41

\section{RCRA legislative history.}

The hearings and floor debates do not cast any direct light on the specific issue of whether Congress meant to waive federal facilities' immunity to civil penalties. ${ }^{42}$ The committee hearings did not include any explicit discussion of applying civil penalties to the federal government. To the extent that civil penalties were discussed at all, witnesses advocated them as a necessary and important enforcement tool. ${ }^{43}$ The always difficult task of ascertaining congressional intent from the legislative record is complicated by the fact that the House and Senate proposed very different federal facility provisions, but did not issue a conference report. The Senate passed its version of RCRA on June $30,1976 .{ }^{44}$ The House de-

40 Resource Conservation and Recovery Act of 1976, Report of the House Committee on Interstate and Foreign Commerce, HR Rep No 94-1491, 94th Cong, 2d Sess 45 (1976).

4702 F Supp at 327. See also State of Ohio, 1990 WL, 77227, *5

${ }^{2}$ See Note, Assuring Federal Facility Compliance with the RCRA and Other Environmental Statutes: An Administrative Proposal, 28 Wm \& Mary L Rev 513, 532-36 (1987); and Kongable, 31 AF L Rev at 30-33 (cited in note 21). For a general discussion of the pitfalls of relying on legislative history, see Cass Sunstein, Interpreting Statutes in the Regulatory State, 103 Harv L Rev 405, 429-34 (1989).

4s HR Rep No 94-1491 at 83-84 (letter from Peter R. Taft, Assistant Attorney General, Land and Natural Resources Division, Department of Justice) (cited in note 39).

14 Vote on S 3622, 122 Cong Rec S21429 (June 30, 1976). 
bated its committee's version on September 27, and agreed to accept, wholesale and with minimal discussion, the Senate's language for the federal facilities provision. ${ }^{45}$

Since the Senate version was the one actually passed, the Senate record is a logical starting point for analysis of the legislative history, at least to the extent one can assume that the House adopted the Senate's intent in passing the Senate version. The Senate Committee on Public Works explained in its report that the federal facilities section requires federal agencies to comply "as if they were private citizens" and demonstrated its awareness of Hancock by specifically mentioning permit systems. ${ }^{46}$ Although these comments do not indicate the Senate's views on civil penalties particularly, they do evince a general intention to treat federal facilities like other polluters.

The legislative history of the House provision reveals that some controversy did exist over the extent to which federal facilities should be subject to state environmental regulation. ${ }^{47}$ The final House version subjected federal facilities only to federally-defined standards, and vested all enforcement authority, including the power to assess civil penalties up to $\$ 25,000$ a day, in the EPA. ${ }^{48}$ The courts in Mitzelfelt and Meyer concluded that since the House version of $\S 6961$ specifically mentioned civil penalties, and the final version did not, Congress, by negative inference, must have intended to exclude the use of civil penalties. ${ }^{49}$ This argument, however, ignores the context in which the change occurred. The Senate version replaced the House proposal entirely. Since civil penalties were not specifically stricken from the provision, the final version's failure to mention them does not prove that Congress intended to exclude them from the scope of the statute.

The Meyer court missed a more subtle but equally speculative argument based on the failed House proposal. The House version included civil penalties only as part of an EPA enforcement scheme; the final version left potential enforcement to the EPA, states, and citizens. Arguably, House members who did not want to give any enforcement powers to the states would not permit states to assess civil penalties, since the latter is merely one type of enforcement power. While it is tempting to conjecture that the House

\footnotetext{
45 Vote on HR 14496, as amended, 122 Cong Rec H32631-32 (Sept 27, 1976).

16 Solid Waste Utilization Act of 1976, S Rep No 94-988, 94th Cong, 2d Sess 23 (1976).

47 HR Rep No 94-1491 at 45 (cited in note 39).

13 Id at 66-67.

19 Mitzelfelt, 903 F2d 1293; Meyer, 644 F Supp at 223.
} 
agreed to allow non-federal enforcement only on the condition that remedies would be severely restricted (e.g., civil penalties would not be available), the legislative record provides no evidence of such a bargain. The House acceded to the Senate version in its entirety, without discussing concessions that would make its approach acceptable to all of the House members. The more plausible explanation is that the Senate federal facilities provision was accepted as one piece of an overall political compromise to get the bill passed; the federal facilities provision was one of about ten items that the House adopted from the Senate version without debate. ${ }^{50}$

The Ninth Circuit in State of Washington made a different use of the legislative history to reject the use of civil penalties on federal facilities. Since the legislative history contained no explicit discussion of state-imposed civil penalties, the court concluded that the waiver of sovereign immunity was not "express and unequivocal." ${ }^{2}$ This approach leads, once again, to the absurd extreme that any standard or requirement not specifically listed in a statute or discussed in Congress cannot be applied to federal facilities.

\section{Post-enactment history.}

Some have used events after RCRA's passage to argue that Congress did not intend to waive federal facilities' immunity to civil penalties. ${ }^{52}$ In 1977, Congress amended the CAA, subjecting the federal government to "all Federal, State, interstate, and local requirements, administrative authority, and process and sanctions .. . to the same extent as any nongovernmental entity." The amended provision also states that the "subsection shall apply notwithstanding any immunity of such agencies ...." 53 The accompanying House Report declared: "The new section . . . is intended to overturn the Hancock case and to express, with sufficient clarity, the committee's desire to subject Federal facilities to all Federal, State, and local requirements-procedural, substantive, or otherwise-process and sanctions." "64 That same year the CWA was

\footnotetext{
so Debate on HR 14496, 122 Cong Rec H32599, H32632 (Sept 27, 1976).

s1 State of Washington, 872 F2d at 879.

${ }^{32}$ See State of Ohio, 1990 WL 77227, *5; Mitzelfelt, 903 F2d 1293; Kongable, 31 AF L Rev at 33-36 (cited in note 22 ).

ss CAA, 42 USC § 7418(a) (1982).

s4 CAA Amendments of 1977, HR Rep No 95-294, 95th Cong, 1st Sess 199 (1977) (emphasis added).
} 
amended with identical language except for the qualification that "the United States shall be liable only for those civil penalties arising under Federal law or imposed by a State or local court to enforce an order or the process of such court."ss

RCRA's language may appear narrower in scope than these amended acts, since $§ 6961$ does not explicitly subject federal facilities to all "administrative authority, and process and sanctions" in addition to "requirements." However, inferring a narrow intent in RCRA's federal facilities provision from a later Congress's treatment of different statutes is a purely speculative endeavor. ${ }^{.6}$ An equally plausible explanation of the differences in wording would be that RCRA was adopted only a few months after Hancock was decided, and Congress had not yet found the best way to phrase a comprehensive waiver of immunity. ${ }^{57}$ Similarly, the special limitation on civil penalties in the CWA can be interpreted different ways. It could suggest that Congress intended different remedies to be available in different environmental areas. Alternatively, the qualification could simply indicate that the general language of the provision allows civil penalties, and that Congress knew how to restrict their imposition when it wanted to.

$* * * *$

Together, the text and history of $\S 6961$ provide the basis for concluding that the provision permits states to assess civil penalties against federal facilities under state law. The language subjects federal facilities to all requirements, whether substantive or procedural, applicable to other solid waste generators. It also provides an illustrative list of such requirements that includes enforcement mechanisms such as sanctions. Federal facilities must obey RCRA "in the same manner, and to the same extent," as any other operation producing solid waste. The circumstances surrounding RCRA's passage make the significance of the language even clearer. The words "all" and "substantive and procedural" were chosen in direct response to the Supreme Court's view that the term "requirements" in other environmental statutes did not encompass enforcement tools. Although an expressio unius argument could be made to exclude civil penalties, the whole thrust of

\footnotetext{
ss CWA, 33 USC \& 1323(a) (1982).

so Even floor debates by later Congresses on a particular statute are not proof of prior intent with respect to that statute. State of Maine, 702 F Supp at 335 n 4, citing United States $v$ Southwestern Cable Co., 392 US 157, 170 (1968).

${ }^{37}$ State of Maine, 702 F Supp at 327-30, 335-38.
} 
RCRA's language and history run counter to an exclusionary canon of construction.

\section{Policy Analysis}

The textual interpretation that allows states to assess civil penalties is consistent with a range of policy objectives and constraints that Congress faces when it chooses to waive the federal government's sovereign immunity. The reasonableness of the outcome from a policy perspective enhances the persuasiveness of the interpretation. In addition, as long as courts continue to reach different interpretations of $\S 6961$, these policy arguments also support the passage of an amendment such as the FFCA that would clarify $\S 6961$ 's intent to waive the federal government's immunity to civil penalties.

Waivers of federal sovereign immunity have become increasingly common in the past century, often prompted by realizations of the growing scope of government wrongs. ${ }^{68}$ Both the Tucker Act, which waived immunity to contract claims in 1887, and the Federal Tort Claims Act (FTCA), in 1946, were precipitated by the inadequacy of private bills in dealing with claims against the government; the Congresses of the 1940s, for instance, were considering over 2000 private petitions for tort compensation each year. ${ }^{50}$ In 1976, the Administrative Procedure Act incorporated a waiver of immunity for administrative wrongs in response to the rapid growth of the regulatory state. ${ }^{60}$ While an occasional government violation might be a tolerable quid pro quo for a government able to operate without interference, such a tradeoff must be reexamined when the government becomes capable of inflicting widespread harm on society. The scope and intractability of federal facility RCRA noncompliance make the issue of civil penalties a pressing one. 1983).

s8 Peter H. Schuck, Suing Government: Citizen Remedies for Official Wrongs 39 (Yale,

${ }^{89}$ Leon Hurwitz, The State as Defendant: Governmental Accountability and the Redress of Individual Grievances 21-22 (Greenwood Press, 1981). Tucker Act, 24 Stat 505 (1887); Federal Tort Claims Act, c 753, 60 Stat 812, Title IV (1946).

${ }^{30}$ Administrative Procedure Act, 5 USC $\$ 702$ (1988). For discussions of the need for judicial review of administrative action, see Roger C. Cramton, Nonstatutory Review of Federal Administrative Action: The Need for Statutory Reform of Sovereign Immunity, Subject Matter Jurisdiction, and Parties Defendant, 68 Mich L Rev 387, 418-28 (1970); and Antonin Scalia, Sovereign Immunity and Nonstatutory Review of Federal Administrative Action: Some Conclusions from the Public-Lands Cases, 68 Mich L Rev 867, 912-20 (1970). 
In the environmental context, the primary values involved in evaluating a waiver are political legitimacy, environmental goals, balance of powers, and federal missions. The following sections will demonstrate that the imposition of civil penalties will further the first two goals without undermining the latter two. One thought to keep in mind is that immunity is already indisputably waived for substantive standards and injunctive relief, so a certain trade-off between the values has already been agreed upon. Therefore, a waiver for civil penalties should be acceptable as long as the arguments for and against it are at least as strong and weak, respectively, for remedies compared to standards, and for civil penalties compared to injunctions.

\section{A. Political Legitimacy}

The common law rationale for sovereign immunity originated with the English notion that the "king can do no wrong." Since the king ruled by the grace of God (rex gratia dei), any complaint against the state would amount to a complaint against God. ${ }^{62} \mathrm{Al}-$ lowing suits against the sovereign without consent would challenge its supremacy and tarnish its image. The logic of this rationale began to lose force, however, as the notion of rex gratia populi (king by grace of the people) became ascendant. ${ }^{63}$ Government in the United States, which has always been based on the sovereignty of the people, seems an especially dubious heir to this rationale for sovereign immunity. Concern with maintaining political legitimacy, which once favored immunizing the sovereign, now suggests exactly the opposite: when the government receives its power from the people, it maintains credibility by subjecting itself to the laws to the same extent as they are applied to the people. ${ }^{84}$

A federal facility that violates environmental laws causes the same environmental problems as any other waste generator, justifying equal application of the laws, including remedies. Hazardous wastes remain hazardous whether they come from federal facilities

o2 Schuck, Suing Government at 30 (cited in note 57). Some controversy exists over whether this maxim really meant that the king could not be sued because he was incapable of doing wrong, or whether in fact it meant that he was not allowed to do wrong. See Note, Suit Against the Sovereign: The Dubiety of the Eleventh Amendment, $90 \mathrm{~W}$ Va L Rev 211, 214 (1987). The existence of petitions of right and the availability of equitable relief through the Court of Exchequer seem to indicate that the king was not only capable of doing wrong, but also could be held responsible. See Schuck, Suing Government at 32-33.

es Hurwitz, The State as Defendant at 10 (cited in note 58).

es Id at 15-18.

of Id at xi-xii; Schuck, Suing Government at 1 (cited in note 57). 
or from private or state or local government operations. In the context of environmental regulation, a facility's status as an operator that generates waste should be as important as its status as a governmental entity.

The state-as-market-participant doctrine provides a useful analogy for determining how to treat government entities that are acting as participants in, rather than regulators of, societal activities. Under this doctrine, states are not subject to Commerce Clause restrictions on their activities when behaving as actors in the marketplace. ${ }^{65}$ The underlying principle is that when government acts as a market participant, it should be treated like one; this principle arguably suggests not only that government should be free from ordinary restrictions on its actions as government, but also that it should be subject to regulations imposed on other market participants.

Federal facilities such as naval shipyards or nuclear materials production plants clearly are not acting as government regulatory bodies. However, because some of the largest federal facilities produce "public goods," such as national defense, they may not seem like ordinary market participants; they seem instead to be fulfilling a governmental function. Nevertheless, the facilities are acting as producers, even if they have a monopoly on the particular market; the value of equal treatment in enhancing political legitimacy should not be confused with concern about the effect on important public functions, which will be addressed below in Section II D. In addition, not all federal facilities perform services that can only be provided by the government. A government-run nuclear plant, for instance, produces energy, and waste, the same way that a privately-owned one does.

Congress has already recognized the political importance of treating federal facilities like other polluters by setting the same standards for federal facilities as for private operations. Mandating compliance with environmental standards is meaningless, however, if no effective remedy for violations exists. RCRA $\$ 6928$ clearly permits the use of civil penalties against private, state, and local government operations. Treating federal entities, the other chief violators of the law, similarly under the statute would enhance the federal government's credibility as an environmental enforcer.

${ }^{85}$ White $v$ Massachusetts Council of Construction Employers, Inc., 460 US 204, 208 (1983); Reeves, Inc. v Stake, 447 US 429, 436-37 (1980). 


\section{B. Environmental Protection}

The ultimate goal of civil penalties is to protect the environment by deterring violations of the environmental laws. The need for effective remedies to achieve this goal should be self-evident. The harder question is whether civil penalties serve this purpose better than, or at least provide a useful alternative to, existing remedies such as injunctions.

The threat of injunctions has thus far not effectively deterred federal facilities' violations of RCRA. Despite the undisputed availability of injunctions and court-ordered sanctions to enforce them, federal facilities have a long record of noncompliance. Reports of "foot-dragging" trant"68 federal facilities were a familiar refrain at the 1989 hearings before Congress on the Federal Facilities Compliance Act. Kentucky's experiences provide some typical examples. At Fort Knox, solvents, pesticides, and waste fuels have been improperly stored in leaking underground tanks, landfills, and lagoons. From 1982 to 1985, the Army "ignored repeated requests to submit an interim status closure plan and was consistently late in submitting its generator annual reports." ${ }^{60}$ PCBs and radioactive elements have been detected in fish, surface water, and groundwater near the Paducah Gaseous Defusion Plant, which produces enriched uranium for reactor fuel use. Nevertheless, the Department of Energy has refused to grant security clearance for state waste management inspectors. ${ }^{70}$ Not all federal facilities have been completely intractable, ${ }^{71}$ and recently some have signed comprehensive compliance agreements. ${ }^{72}$ Strong enforcement options remain a necessity, however, both to preserve incentives for federal facilities to enter into environmentally rigorous agreements, and to make those agreements "worth the paper [they are] written on.""3

\footnotetext{
so Hearings on Federal Compliance at 56 (statement of Thomas C. Jorling, Commissioner, New York State Department of Environmental Conservation) (cited in note 6).

or Id at 72 (statement by Russell Barnett, Deputy Commissioner, Kentucky Department for Environmental Protection).

6s Id at 26 (statement by Jim Jones, Attorney General, Idaho).

69 Id at 73.

${ }^{70}$ Id. See also id at 10 (Nevada); 16-17 (Washington); 27 (Idaho); 56 (New York); 65 (Pennsylvania); and 68 (North Carolina).

21 New York, for instance, reports that many of the violations found are corrected on schedule. Id at 56 .

${ }^{72}$ For example, the state of Washington, DOE, and EPA have recently proposed a comprehensive agreement to bring the Hanford Reservation into RCRA compliance. Id at 21 (statement by Kenneth O. Eikenberry, Attorney General, State of Washington).

${ }^{73}$ Id.
} 
The reasons for the ineffectiveness of injunctive remedies to date are not entirely clear. A key difference between injunctions and civil penalties, however, is that the former only present a threat that a court will someday, after lengthy proceedings, tell a facility to stop violating the law. Civil penalties, on the other hand, accrue as violations occur, giving facilities an incentive for immediate compliance, even though penalties will not actually be assessed until a court proceeding is completed. ${ }^{74}$ For instance, if a facility is charged with having leaking storage tanks in 1990, it can continue its practice with impunity until a court issues an injunction, perhaps several years later. If, however, civil penalties are available, the agency knows that it will be held liable for all violations after 1990.

Because federal facilities are publicly-funded nonprofit enterprises, monetary penalties may not be completely effective deterrents. For example, penalties may not eliminate "capacity-based illegality"7s_-violations resulting from insufficient appropriations by Congress. However, budgetary constraints can be an obstacle to the effectiveness of injunctions as well. More importantly, in the context of most RCRA violations, budget constraints should not be insurmountable. ${ }^{76}$ Since RCRA focuses on "housekeeping" measures, ${ }^{77}$ the most common types of violations are failures to analyze wastes, obtain permits, properly store wastes, keep records, train personnel, and develop contingency plans. ${ }^{78}$ Therefore, compliance, although not costless, is not expensive, especially compared to clean-up. Furthermore, subjecting federal facilities to civil penalties should help to eliminate the capacity problem by forcing Congress and the agencies to give priority to compliance funding.

Penalties have one potential problem that injunctions do not: the use of monetary penalties may seem futile and illogical when the payments will ultimately come from the public treasury. In contrast to private entities, federal facilities do not have profit mo-

74 Confirmed in author's telephone conversations with Dennis Harnish, Assistant Attorney General, Maine, and Jack Van Clay, Assistant Attorney General, Ohio (April 20, 1990).

7s Schuck, Suing Government at 6-8 (cited in note 57).

${ }^{76}$ See Donald W. Stever, Perspectives on the Problem of Federal Facility Liability for Environmental Contamination, 17 Envir L Rptr 10114, 10115-16 (1987), for a discussion of ways in which agencies can meet fiscal constraints.

${ }^{77}$ Phone conversation with Harnish, Maine Assistant Attorney General (cited in note 74).

${ }^{78}$ See, for example, State of Washington, 872 F2d at 876; Meyer, 644 F Supp at 222; and State of Ohio, 689 F Supp at 761. Confirmed in author's conversations with Van Clay, Ohio Assistant Attorney General, and Harnish, Maine Assistant Attorney General (cited in note 74). 
tives that require internalizing the cost of penalties. ${ }^{79}$ Although the current RCRA does not specify the source of payment for the civil penalties, the approach currently used in the CAA (guided by a 1979 Comptroller General opinion and cited with approval by the House report on the proposed FFCA) requires that a federal agency conceding liability pay the penalty out of its operating funds. ${ }^{80}$ If the agency disputes liability, the payment comes from the "judgment fund" appropriation under 31 USC \& 1304, rather than agency funds. ${ }^{81}$ Unfortunately, this method allows federal agencies literally to pass the buck for environmental compliance along to the judgment fund. It also discourages the concession of liability, hampering environmental enforcement. However, civil penalties can be structured to make them effective deterrents in the federal facilities context. Federal agencies may not have to turn profits, but they do "compete" with other agencies for funds, which they certainly seek to maximize. ${ }^{82}$ If culpable agencies are directly charged for their violations, disputed or not, they should react to the penalties. ${ }^{83}$

In the absence of thorough empirical studies, the best evidence of the effectiveness of civil penalties against publicly-funded organizations is their widespread use against state and local governments and the apparently better compliance records of these actors. ${ }^{84}$ Ironically, the federal government vigorously exercises the remedy from which it wishes to shield itself: between 1983 and 1988, approximately ninety percent of the civil environmental suits filed by the federal government against state and local governments sought civil penalties. State and local agencies in every state except Delaware have been subject to penalties, ranging from $\$ 1$ to $\$ 1,000,000 .{ }^{85}$ State and local governments are also subject to penalties under state environmental laws.

70 Schuck, Suing Government at 107 (cited in note 57).

${ }^{\text {so }}$ HR Rep No 101-141 at 41-42 (cited in note 1).

s2 Id. Title 31 is the Money and Finance statute; $§ 1304$ provides a standing appropriation for money to pay judgment awards against the United States.

s3 Hearings on Federal Compliance at 34 (statement of Kenneth O. Eikenberry, Attorney General, Washington) (cited in note 6).

ss Schuck, Suing Government at 107-08 (cited in note 57).

or Comprehensive data on state and local government compliance simply is not available. At best, their better compliance record relative to federal facilities can be inferred from the general absence of complaints. As Jim Jones, Attorney General of Idaho states, "Frequently, States have more difficulty obtaining Federal agency compliance with hazardous waste management programs than resolving similar issues with private parties [or] State or local governmental entities." Hearings on Federal Compliance at 26 (cited in note 6).

${ }^{83}$ Hearings on Federal Cleanup at 218-28 (cited in note 9). 
C. Separation of Powers

1. Executive versus judicial power.

Suits against federal facilities, whether to impose standards or remedies, implicate the seperation of powers between the executive and judicial branches. A fear of "undue judicial interference" with executive functions often underlies debates about sovereign immunity. ${ }^{86}$ In 1882 , Justice Gray, dissenting in United States $v$ Lee, complained of the executive being "dispossessed by judicial process." More recently, the Supreme Court stated in Larson v Domestic \& Foreign Commerce Corp. that the "interference of the Courts with the performance of the ordinary duties of the executive departments of the government, would be productive of nothing but mischief." 88

According to the theory of checks and balances, however, the executive should neither be subordinate to the judiciary nor entirely free of constraints. Allowing civil penalties for violations of the RCRA need not tip the balance of power excessively; because the RCRA already states that federal facilities must comply with environmental regulations, giving the courts the power to remedy violations only gives them the authority to enforce rules to which the executive is already subject.

In addition, civil penalties will not affect the seperation of powers any more than injunctive relief already does, since penalties require less judicial intrusion. Injunctive remedies depend on close judicial examination of specific factual situations, and judicial determination of particular agency actions. ${ }^{80}$ Penalties also give courts influence over agency behavior, but let the agencies make specific decisions based on their own internal calculus. In this respect, the use of civil penalties rather than injunctive relief accords the federal government more control over the execution of its policy, not less.

\section{Federal versus state power.}

Permitting state governments to assess penalties against federal facilities implicates another separation of powers issue, a federalism concern with both a structural and a practical component.

ss Cramton, 68 Mich L Rev at 397 (cited in note 59).

87106 US 196, 226 (1882) (Gray dissenting). (1840).

337 US 682, 704 (1949), quoting Decatur v Paulding, 39 US (14 Peters) 497, 516

89 Schuck, Suing Government at 15-16 (cited in note 57). 
Our structure of government demands a certain allocation of power between federal and state government. Giving states the power to penalize federal facilities arguably misallocates that power, but the context in which it would be given suggests otherwise. Much of the nation's environmental legislation relies on state implementation, on the theory that state governments are better situated to address local problems.90 The federal facilities provisions, moreover, already give state governments the underlying power to establish environmental standards to which the federal government may be held accountable; putting enforcement power in the states' hands gives them nothing more than the ability to make those standards meaningful. Furthermore, to the extent that civil penalties interfere less directly with agency action, as discussed above, they give states no more disruptive power than injunctions.

A specific structural concern is that the penalty power may give states too much control over federal funds. ${ }^{91}$ However, several built-in safeguards limit potential abuse. First, states have little incentive to seek unjustified penalties. State attorneys general recently testified before the House of Representatives that their focus is on obtaining compliance, not collecting penalties; ${ }^{92}$ although such statements may be self-serving, it seems logical that states would undermine their own effectiveness and credibility as enforcers if their penalties were not carefully tailored..$^{93}$ Second, penalty amounts are usually calculated according to formulas tied closely to violations. ${ }^{94}$ Third, the federal government can always challenge penalties in court, ${ }^{95}$ and when the federal government is the defendant the forum will be federal court, where the facility presumably will be protected from egregious state attempts at self-dealing. Fourth, some states require that penalties be paid into

of Hearings on Federal Compliance at 26 (statement of Jim Jones, Attorney General, Idaho) (cited in note 6). See also Note, $28 \mathrm{Wm} \&$ Mary L Rev at 513 (cited in note 41).

-1 Hearings on Federal Compliance at 95 (statement of William H. Parker III, Deputy Assistant Secretary of Defense for the Environment, that penalties would have "the unfortunate side effect of siphoning funds.") (cited in note 6). The fear is that states will use their penalty power to "raid" the federal treasury. See also statements by Kenneth $O$. Eikenberry, Attorney General, Washington, id at 20; Representative Dan Schaefer, Colorado, id at 36; Jim Jones, Attorney General, Idaho, id at 37; and Representative Dennis Eckart, Ohio, id at 74.

22 See generally HR Rep No 101-141 at 6-39 (cited in note 1).

os See Hearings on Federal Compliance at 74 (statements by Thomas C. Jorling, Commissioner, New York State Department of Environmental Conservation, and Arthur A. Davis, Secretary, Pennsylvania Department of Environmental Resources) (cited in note 6).

os Id at 75 (statements by Richard L. Shank, Director, Ohio Environmental Protection Agency, and Thaddeus B. Wester, Deputy Health Director, North Carolina).

${ }^{95}$ Id. 
environmental response funds, removing any incentive for states to use environmental penalties to acquire funds for unrelated state programs. ${ }^{96}$ Finally, the best data available suggest that states have not abused the civil penalty provisions under the CAA, CWA, or RCRA. ${ }^{97}$ The highest total amount sought by a state against a federal facility for RCRA violations was $\$ 125,000$, and this was against the DOE's notoriously noncompliant facility in Ohio. ${ }^{98}$ Other penalties have ranged from $\$ 61$ to $\$ 92,000$. The average amount sought was less than $\$ 23,000$, and the average amount actually collected was $\$ 4,750$. $^{\text {9 }}$

The practical component of this federalism objection focuses on the administrative difficulties federal agencies face in complying with fifty different sets of regulations. Again, given that federal facilities must follow state standards, adding enforcement to state powers should not make compliance any harder than it already is. In fact, when the requirements are state or local, enforcers at the state level may be better equipped to properly determine violations and penalties.

One fear is that states will undermine the "worst first" priority scheme that federal agencies have devised for cleaning up federal facilities, ${ }^{100}$ because agencies will have to take action in the states that happen to be most aggressively enforcing civil penal-

O6 Ohio Rev Code Ann $\S 3734.13$ (C) and (E) (Anderson, 1988 and Supp 1989). See also Hearings on Federal Compliance at 25, 214, for documentation of similar programs in Idaho and Virginia (cited in note 6). Maine, however, is an example of a state where collected penalties simply go to the state treasury. $38 \mathrm{Me}$ Rev Stat Ann § 349(2) (West 1989 and Supp 1989).

87 Hearings on Federal Compliance at 39-41 (letter from National Association of Attorneys General (NAAG)) (cited in note 6). In response to a request by the House Subcommittee on Transportation and Hazardous Materials, the NAAG compiled information on environmental penalties assessed by fourteen states against federal facilities under state and federal environmental laws. According to the survey, most penalties were well under $\$ 50,000$; the two outlier penalties, $\$ 125,000$ and $\$ 500,000$, were at Fernald in Ohio and the Vandenburg Air Force Base in California, both sites with long histories of egregious violations. Jonathan Z. Cannon, Acting Assistant Administrator of the Office of Solid Waste and Emergency Response at the EPA, also testified before Congress that EPA had no knowledge of existing state abuse of penalty power. Id at 129 .

${ }^{98}$ See generally DOE: Pollution at Fernald, Ohio, Hearing on HR 3783, HR 3784, and HR 3785 before the Subcommittee on Transportation, Tourism, and Hazardous Materials of the House Committee on Energy and Commerce, 100th Cong, 2d Sess (1988).

${ }^{9}$ HR Rep No 101-141 at 40 (cited in note 1). These penalty figures exist because states calculate RCRA penalties despite the possibility that federal facilities will resist payment. In some cases, federal facilities will pay an amount agreed to in a settlement, although they are reluctant to concede that they have paid a penalty. Confirmed in author's telephone conversation with Van Clay, Ohio Assistant Attorney General (cited in note 74).

100 Hearings on Federal Compliance at 95, 102 (statements by William H. Parker III, Deputy Assistant Secretary of Defense for Environment, and Leo Duffy, Special Assistant to 
ties. ${ }^{101}$ The bulk of RCRA enforcement activity, however, is directed at obtaining compliance with RCRA's cradle-to-grave preventive measures, such as recordkeeping and proper storage. The need to set priorities among facilities should not be so urgent for those relatively inexpensive measures; clean-up activities, in contrast, may require so many dollars that immediate concurrent clean-up is nearly impossible. ${ }^{102}$ States do have the authority under $\S \S 6924(\mathrm{u})$ and 6928(h) to seek corrective action, which theoretically could include clean-up activities, but the Comprehensive Environmental Response, Compensation, and Liability Act (CERCLA) is intended to cover most clean-up activities. ${ }^{103}$

To the extent that interference with agency priorities is a valid concern, it is not unique to civil penalties; injunctions sought by states, which are clearly permitted under RCRA, will influence federal agency behavior in the same way. Two considerations also mitigate the severity of this concern. First, penalties may force Congress to appropriate more funds for environmental compliance, thus eliminating some of the need for ranking compliance activities. In addition, states with the most aggressive enforcement efforts may well be those with the worst federal facility environmental problems.

Giving states penalty powers undeniably creates the potential for some problems, but those problems must be evaluated in the context of the possible alternatives, not in a vacuum. For instance, unless the EPA is given exclusive enforcement authority, the problem of state interference with federally set priorities will arise no matter what the particular enforcement mechanism. ${ }^{104}$ Although a full discussion of the relative merits of federal versus state enforcement is beyond the scope of this Comment, the fact that alterna-

the Secretary of Energy for Coordination of DOE Environment and Waste Management) (cited in note 6).

${ }^{101}$ HR Rep No 101-141 at 49 (letter from L. Niederlehner, Deputy General Counsel, Department of Defense) (cited in note 1).

${ }^{102}$ Hearings on Federal Compliance at 106-09 (DOE's five-year plan for prioritizing clean-up), and 127-28 (statement by Leo Duffy, Special Assistant to the Secretary of Energy for Coordination of DOE Environment and Waste Management, explaining that the prioritization plan is not necessary for ordinary RCRA compliance measures) (cited in note 6).

${ }^{103} 42$ USC $\S \S 6924(\mathrm{u})$ and 6928(h). Hearings on Federal Cleanup at 412, 419-21 (statement of J. Winston Porter, Assistant Administrator for Solid Waste and Emergency Response, EPA, outlining strategy in cases of RCRA/CERCLA overlap) (cited in note 9). The proper interaction between the two statutes is a matter of ongoing dispute. See State of Colorado v United States Department of the Army, 707 F Supp 1562 (D Colo 1989) (holding that CERCLA does not preempt injunctive relief for RCRA violations).

${ }^{106}$ As pointed out in note 10 above, however, federally coordinated enforcement has its own legal difficulties, and is not currently available. 
tive enforcers will have their own disadvantages and advantages is worth keeping in mind.

\section{Federal Missions}

The most powerful objections to immunity waivers are based on waivers' effects on federal government functions. In dissent in Lee, Justice Gray voiced fears about allowing the government to be sued for appropriating land for military purposes. ${ }^{105}$ Courts have continued to be reluctant to find waivers of immunity for monetary penalties because agency funds would have to be spent on penalties or compliance, rather than the agency's primary mission. ${ }^{106}$ Opponents of civil penalties warn particularly of the threat to national security that sanctions against the Department of Defense (DOD) might create: "Federal agencies exist and are explicitly funded to perform a function for the public good and cannot simply go out of business or go bankrupt. . . . Use of DOD funds to pay fines and penalties diverts funds from the specific defense mission ....."107

Civil penalties need not unduly interfere with the undeniably important functions that DOD and other federal agencies perform. ${ }^{108}$ The oddest aspect of this concern is that it assumes that compliance will not occur, and that penalties will have to be paid, depriving the agency of some of the resources it could have spent on its mission. The main objective of waiving immunity to penalties is to create a deterrent to agency environmental violations, and an incentive for Congress to allocate necessary compliance funds, not to actually collect the fine. To the extent that penalties are indeed assessed, many of the same safeguards that preserve a bal-

103 Lee, 106 US at 226 (Gray dissenting).

${ }_{100}$ The Supreme Court first addressed the issue of penalties against the government in Missouri Pacific Railroad Co. $v$ Ault, 256 US 554, 558 (1921). The relevant statute provided that government railroad operators "shall be subject to all laws and liabilities as common carriers ...." However, the Court concluded that "Congress is not to be assumed to have adopted the method of fines paid out of public funds to insure obedience to the law on the part of the Government's railway employees." Id at 563-64. The restrictive attitude towards penalties in Ault has since been applied in the interpretation of other statutes as well. See Matter of Sparkman, 703 F2d 1097, 1100-01 (9th Cir 1983) and Smith v Russellville Production Credit Association, 777 F2d 1544, 1549-50 (11th Cir 1985) (both cases holding federally-organized credit associations, formed to help small farmers, exempt from punitive damages); Painter v Tennessee Valley Authority, 476 F2d 943, 944-45 (5th Cir 1973) (TVA immune from punitive damages).

${ }^{107}$ HR Rep No 101-141 at 49 (letter from L. Niederlehner, Deputy General Counsel, Department of Defense) (cited in note 1).

108 Note that concerns about public missions have not prevented the assessment of penalties against state and local governments. See text at notes 83-84. 
ance between federal and state power-such as the need to maintain credibility, penalty formulas, and environmental response funds-will prevent excessively high penalties.

Civil penalties may interfere with agency missions when they effectively deter agencies, since this will force agencies to use funds for environmental compliance. Injunctions, however, create the same interference by mandating compliance. More importantly, the use of funds for compliance seems to accord with Congress's intent in subjecting agencies to environmental standards, and thus may be an acceptable degree of interference with agency missions. No matter how important an agency's particular mission might be, it should not override Congress's intent to protect the environment. If the amount of resources being diverted seems excessive, the problem is not the availability of penalties, but the level of environmental standards that have been set by Congress and the states. Forcing environmental compliance should also preserve money for agencies' primary functions in the long run by preventing cleanup costs. ${ }^{108}$ Congress, in fact, seems already to have struck the balance in favor of environmental compliance by creating a narrow exemption for federal facilities only when compliance threatens a "paramount interest of the United States."110

Paradoxically, civil penalties must interfere to some extent with a facility's operations if they are to be an effective deterrent. In discussing the possibility of fining officials, Professor Peter Schuck suggests a solution to the dilemma: the penalties "must be both modest in amount (so vigorous decisionmaking is not chilled) and more or less automatic (so the deterrent is credible)."111 This solution applies as well to agency fines; penalties, if modest, will permit agencies to fulfill their functions, and will serve as an effec-

${ }^{109}$ HR Rep No 101-141 at 7, 10 (statements of Randall Mathis, Acting Director, Arkansas Department of Pollution Control and Technology, Charles M. Oberly III, Attorney General, Delaware, and Larry Morgan, Deputy General Counsel, Florida Department of Environmental Regulation) (cited in note 1).

11042 USC $\$ 6961$ (1982). The president has exercised this exemption power only once so far. In 1981, President Ronald Reagan issued an executive order exempting Fort Allen, in Puerto Rico, from RCRA, CAA, CWA and Noise Control Act (NCA) requirements based on a finding that the need to immediately relocate and house Haitian refugees represented a "paramount interest." Executive Order 12,327, 3 CFR 185 (1981). The statute clarifies the narrow scope of the "paramount interest" language in the following sentence: "No such exemption shall be granted due to lack of appropriation unless the President shall have specifically requested such appropriation as part of the budgetary process and the Congress shall have failed to make available such requested appropriation."

11 Schuck, Suing Government at 108 (cited in note 57). 
tive deterrent if their imposition is a predictable consequence of noncompliance.

\section{ConCLUSION}

The current language of RCRA $\S 6961$, both on its face and in its historical context, supports the conclusion that federal facilities should be subject to civil penalties for violations of environmental standards. The use of civil penalties satisfies, or can be tailored to satisfy, a range of policy concerns, including political legitimacy, environmental protection, separation of powers, and federal missions. Making broad enforcement powers available against federal facilities meshes with the current development of public law. Public law rights are particularly dependent on effective remedies because the costs of compliance are often high while the incentives, in the absence of individual accountability, are low. ${ }^{112}$ Viewed in this context, the vigorous application of civil penalties seems not only sensible but also necessary. 